\title{
CONTRIBUIÇÕES DAS AÇÕES DE DESPERTAR VOCAÇÕES: O CASO DA VISITA GUIADA A UM CAMPUS AGRÍCOLA
}

\section{CONTRIBUCIONES DE LAS ACCIONES DE DESPERTAR VOCACIONES: EL CASO DE UN TOUR GUIADO A UN CAMPUS AGRÍCOLA}

\section{CONTRIBUTIONS OF AWAKENING VOCATIONS' ACTIONS: THE CASE OF A GUIDED TOUR TO AN AGRICULTURAL CAMPUS}

\author{
Karoliny Paula da Silva ${ }^{1}$; Erick Viana da Silva ${ }^{2}$
}

DOI: https://doi.org/10.31692/978-65-991061-9-4.100-103

\section{INTRODUÇÃO}

O Programa Despertando Vocações (PDV) é um projeto que integra ações de ensino, pesquisa, extensão e gestão proposto pelo IIDV (Instituto Internacional Descobrindo Vocações), que é subdividido em categorias que visam facilitar a integração dos discentes e docentes em suas áreas, são elas: Gestão e Tecnologia (PDVGT), Saúde (PDVS), Ciências Agrárias (PDVAgro) e Licenciaturas (PDVL).

O PDV tem como objetivo aproximar o discente do universo acadêmico, propondo como principal ponto o protagonismo acadêmico, ou seja, uma metodologia ativa na qual o discente promove primordialmente o seu processo educativo e o docente é concebido como um facilitador e mediador do conteúdo teórico, unindo-o com a realidade (MARCOS, 2018). Antes de atuar diretamente no PDV, o aluno passa por uma preparação acadêmica, para que ele desenvolva as competências necessárias para desempenhar as atividades propostas, essa formação é denominada de I9 PDV. Os cursos oferecidos durante esta capacitação não são voltados apenas para o programa em si, mas podem ser aproveitados durante toda a vida pessoal e acadêmica, tornando-se uma oportunidade do estudante conectar-se e cooperar com áreas distintas. Alguns dos cursos oferecidos são: Introdução à oratória, introdução à fotografia, marketing pessoal, planejamento acadêmico, introdução ao gerenciamento de projetos, gestão humanizada de pessoas, Arduíno, dentre outros.

A partir desse princípio, algumas atividades são fundamentais dentro do projeto, como minicursos ofertados pelos alunos que fazem parte da extensão, reuniões de troca de experiência acerca do programa, grupos de trabalho que tomam conta das partes funcionais e fundamentais do PDV e, dentre outras práticas, as visitas guiadas a outros campus. O último item é o que será retratado no presente documento, mais especificamente a visita guiada ao IFPE Campus Vitória,

\footnotetext{
${ }^{1}$ Graduanda em Psicologia, Universidade dos Guararapes, karolinypaula.pt@ gmail.com

${ }^{2}$ Mestre em Administração, IFPE - Campus Recife, erick.viana@ recife.ifpe.edu.br
} 
que foi ministrada pelo PDVAgro e teve por objetivo contextualizar os alunos com as atividades exercidas em um campus com enfoque nas ciências agrárias, em concomitância a fazer com que os alunos do PDVGT do IFPE Recife se apropriassem dos elementos necessários para o planejamento e execução de uma visita guiada, para que fosse posta em prática no campus de origem.

\section{RELATO DE EXPERIÊNCIA}

A visita técnica aconteceu no dia 06 de maio de 2019, nos reunimos no IFPE Campus Recife às sete manhã, e saímos às oito da manhã em direção ao Campus de Vitória de Santo Antão. Ao chegarmos em nosso destino, tivemos uma reunião com os professores do local, que explicaram um pouco mais acerca dos cursos ofertados e da influência do PDVL e do PDVAgro na escolha profissional dos jovens.

A instituição conta com os cursos de licenciatura em Química; bacharelado em Agronomia; subsequentes em Agricultura, Agroindústria e Zootecnia; Proeja em Manutenção e Suporte em Informática; e integrados em Agroindústria e Agropecuária. Os cursos são de extrema importância para a comunidade acadêmica, visto que a cidade de Vitória e as circunvizinhas tem sua economia movida a partir de atividades ligadas ao cultivo de animais e plantas para os mais diversos fins.

Durante a reunião primeira, foi falado que alguns moradores acham que o IFPE é uma escola particular de alto custo devido ao seu grande porte, as visitas guiadas entram nesse ponto também para desmistificar essa crença, além de cativar os futuros alunos a ingressarem nos cursos. Outra problemática que o Campus vinham enfrentando, que está sendo pauta em outros âmbitos da educação, é o contingenciamento de gastos proposto pelo Governo Federal, que coloca em risco a oferta de bolsas e até mesmo do restaurante do campus, elementos cruciais para que estudantes oriundos de famílias de baixa renda continuem nos seus cursos.

Após o momento de reflexão proposto, caminhamos para conhecer os cultivos do Campus, que tem um território enorme com diversos tipos de plantações e criações de animais, como coelhos, codornas, porcos, galinhas, peixes e camarões. A plantação cultivada é submetida a uma quantidade reduzida de agrotóxicos possíveis, havendo diversas amostras e pesquisas em andamento, o que demonstra uma preocupação com as questões de saúde, tanto do Campus, afinal tudo que é produzido serve para alimentar o restaurante interno, quanto de forma geral, afinal, as pesquisas podem ajudar na diminuição do uso desses produtos futuramente.

Vale ressaltar que as atividades acima foram propostas pelo PDVAgro, que são 
utilizadas geralmente para que o aluno em idade de decisão de sua trajetória laboral e acadêmica possa ter contato real com a área que o cerca constantemente, visando que ele entenda melhor o processo e permita-se ser cativado (ou não) pelos conhecimentos propostos.

Depois desse momento, houve uma pausa para o almoço e a continuidade dada ao momento pelo PDVL composto pelos licenciandos em Química, que fizeram vários experimentos dentro da área deles, contextualizando com o cotidiano dos alunos, com memes de conhecimento geral do público jovem e também com o "Passinho dos Malokas", ritmo atual que se popularizou no estado por meio das redes sociais. No final da apresentação do curso, houve uma conversa de saldo positivo e negativo e o que poderia ser proposto por cada curso do IFPE de Recife durante uma visita técnica para chamar a atenção do aluno para o curso. Foi de grande valia e cativou a todos, deixando a semente da reflexão para que pudesse germinar e ser frutífera.

No final houve um momento de maior descontração, apesar de que o saber acadêmico não foi deixado de lado. Conhecemos como era feito o processo para transformar a matéria prima nas comidas que compramos no supermercado, a partir do saber da Agroindústria. Foi possível ter acesso a iogurte produzido dentro do próprio Campus e pronto para consumo, tivemos acesso a como era produzida a farinha, queijos, licores, açúcar e outros produtos orgânicos. No final, ainda pudemos raspar cana para fazer o nosso próprio caldo de cana. $\mathrm{O}$ resultado foi positivo, todos os alunos saíram muito satisfeitos com a visita, foi impressionante como muitos dos estudantes que eram do integrado e, consequentemente, mais novos, nem sabiam como era moída a cana e nunca tinham visto uma moenda, mostrando a necessidade desse resgate de valores e cultura para os jovens.

\section{CONSIDERAÇÕES FINAIS}

Durante toda a visita, conseguimos perceber a importância de cativar o jovem para áreas do conhecimento que ele vê no cotidiano, mas talvez não entenda a fundo. Esse momento de escolha laboral resulta em um enorme estresse, o jovem precisa de influência da família, dos amigos, psicológica e de todos os âmbitos ao seu redor para poder lidar bem com o momento e escolher para qual direção ir. A iniciativa da visita técnica pode ajudar quem passa por essa situação a achar esse desejo interno e seguir sua profissão, minimizando a evasão dos cursos e aumentando a satisfação dos alunos.

Além disso, a forma próxima utilizada para passar o conteúdo, em concomitância com o planejamento, é uma tática para aproximar ainda mais o jovem do local, para que ele se perceba como parte integrante do ambiente, e não como externo. 
Enquanto estudante de psicologia, ao visitar um campus voltado majoritariamente para as ciências agrárias, pude constatar como o contato com a natureza, o campo e os fazeres laborais rurais podem servir como estratégia de combate para fatores estressores.

Não obstante, a visita foi importante para nós, que mesmo já estando, tecnicamente, seguindo uma carreira acadêmica, pudemos resgatar fatores primordiais da nossa cultura e conhecer os comportamentos e costumes de uma cidade que não a nossa, que mesmo sendo relativamente próxima, já traz consigo uma enorme quantidade de diferenças que pudemos conhecer e reconhecer.

\section{REFERÊNCIAS}

INSTITUTO IDV (Recife). Breve Histórico. 2019. Disponível em: <https://pdv.institutoidv.org/blog/quem-somos-nos/>. Acesso em: 20 jul. 2019.

MARCOS, L. Metodologias Ativas: O Protagonismo Acadêmico. Estácio Saúde, Santa Catarina, v. 7, n. 2, p.1-5, jul. 2018. Semestral. Disponível em: <http://periodicos.estacio.br/index.php/saudesantacatarina/article/view/5446/47964941>. Acesso em: 18 jul. 2019. 